\title{
Examining the Effects of Digital Animation Integrated into the Mathematics Teaching
}

\author{
Der-Ching Yang* \\ Graduate Institute of Mathematics and Science Education, National Chiayi University, Taiwan
}

Submission: February 04, 2019; Published: May 08, 2019

"Corresponding author: Der-Ching Yang, Life-Time Distinguished Professor, Graduate Institute of Mathematics and Science Education, National Chiayi University, 85 Wen Lung, Ming-Hsiung, Chiayi, 621, Taiwan

\begin{abstract}
The purpose of this study was to examine the students' learning effect when the digital animation activities were integrated into mathematics teaching. Generally, the normal mathematics classroom is tedious and abstruse for students, which may cause students' dislike to mathematics. Three sixth-grade students joined the case study. The results showed that using digital animation could promote students' interest in mathematics learning and improve students' concepts of mathematics. The integration could make the mathematics course more interesting and more connecting to daily life situations.
\end{abstract}

Keywords: Digital Animation; Mathematics Teaching; Learning Interest

\section{Introduction}

Nowadays, with advanced technology and universal internet, many new developments of computers or calculators can be used to assist mathematics teaching. In addition, research studies indicated that technology can enhance students' mathematics concept development efficiently [1,2]. The integration of digital animation into mathematics teaching can bring a new bright to mathematics class. Earlier studies pointed out that integrating digital animation into mathematics classrooms can help students' mathematics learning and raise their mathematics learning interest [3-5]. To sum up, researchers claim that integrating digital animate activities of number sense into mathematics classroom can aid students' number sense ability development and learning interest [6].

Based on the above motivation, this study aimed to investigate the situation of integrating digital animation into mathematics classroom and observed the benefit of this kind of teaching method for students' mathematics learning.

\section{Background}

\section{The Importance of integrating information technology into mathematics classroom}

People in this generation can't live without technology from earlier computer to recent smart phone, and even Wi-Fi as well, which means that technology integrates into our life insensibly. The significant invention also affects modern classrooms, which is full of advanced and various technology. These tools can make teaching more convenient for teachers and students. It is common for computer projector used in every classroom and with universal of electronic interactive whiteboard, electronic book bag, and IRS classroom immediate feedback system; the blueprint of "future classroom" is more evidently. Therefore, the technology is used as teaching assistant tools in the mathematics classrooms which is common sense $[1,7]$.

\section{The Importance of teaching number sense in primary} school

Why is teaching number sense for elementary school students so important? Several reasons can be used to highlight its importance. First, number sense is highly connected to our daily life situations. For example, children need to make sense the meanings of 1 meter, $1 \mathrm{~km}$ of $1 \mathrm{~kg}$ and so on [6]. Second, number sense encourages students to develop flexible and efficient approaches to solve problems $[6,8,9]$. For example, when students were asked to find the answer to $24 \times 25 \div(8 \times 5)$, children usually tended to use rule-based method to calculate the answer: $24 \times 25=$ $600,8 \times 5=40$, and then $600 \div 40=15$.

However, if students have good number sense, they should quickly find the relationships among these numbers. This will help them quickly find the answer, such as $24 \div 8=3$ and $25 \div 5$ $=5$ and then the answer is $3 \times 5=15$, which is more flexible and efficient way to decide the answer. Third, earlier studies showed that number sense is a good predictor for future mathematics achievement to primary school children Jordan, Glutting, Ramineni 
(2010) Yang \& Li (2008). For example, the findings of Yang \& Li (2008) showed that number sense is significantly correlated with fifth grade students' mathematics achievement. Fourth, earlier studies showed that mathematics teaching overemphasized on standard written algorithm may limit students' thinking and reasoning, however number sense can promote students to develop flexible thinking and reasoning [6].

\section{Integrating digital animation into mathematics classrooms related studies}

If teaching activities and content cannot attract learners' attention, they will be distracted easily which leads to decrease their learning motivation and learning effect. Earlier study suggested that the use of technology can attract students' learning interest and concentration [5]. Interest is always the most important issue to trigger learning; therefore, in a successful teaching, the interaction between teacher and students should be active. According to students' degree and need, teacher can observe students' performance by interaction and further can adjust their own teaching method. Teacher only has little time to interact with students using traditional lecture, but if teacher use computer technology, they can let interaction become more frequently.

Because mathematics concepts become more difficult and tedious in higher grade levels, many students have given up mathematics insidiously once they enter higher grade levels. If we can use technology efficiently in mathematics classes, then we can raise students' learning motivation and learning interest. In addition, if we can let students' concentration focus on the mathematics learning as well as they play video games, learning mathematics would not be a nightmare for students anymore. As a matter of fact, the use of interactive media can support students' learning $[10,11]$. Assisted by information technology and multimedia teaching mode, learning mathematics is not merely an abstract thinking system but a concrete and visible method. Integrating information technology into mathematics classroom can change the way teacher teaches which is one-way mode to two-way mode.

\section{Research Design and Method}

This study applied structural interview method and the participants were three six-graders which joined the study.

\section{Sample}

Three (S1, S2, and S3) six-grade students from one public elementary school from southern Taiwan. Were selected to join this study. S1, S2, and S3 belonged to low, middle, and highlevel mathematics performance based on the mathematics test scores from school tests. After activities, we started to interview immediately, and the time for interview was about 50 minutes for each student.

\section{Data analysis}

We recorded the whole interview process and further coded, categorized and analyzed data as (Table 1).

Table 1: The table of original data coding.

\begin{tabular}{|c|c|}
\hline Code Name & The Meaning of Coding \\
\hline Q & Researcher \\
\hline S1?S2国3 & Belonging to low, middle, and high-level performance on mathematics \\
\hline
\end{tabular}

\section{Interview instrument}

The interview outline and questions were designed by the author based on the research purpose. The interview outline for students focused on the students' feeling about the use of digital animation and the effects of mathematics learning. In addition, the interview instrument included eight items and described as follows:

a) Comparing with previous studying method, what differences do you feel?

b) Did you like mathematics class, and why?

c) How do you feel that teacher use digital animation materials?

d) Do you like mathematics more if teacher uses digital animation materials, and why?

e) Do you feel there are any differences between previous and now learning atmosphere in class, and why?

f) Is there any inspiration for your mathematics studying, and why? g) Is there any help for your mathematics concept if teacher uses the digital animation materials, and why?

h) Do you still hope that teacher uses the digital animation materials in class, and why?

During the interview, the processes of interviewing were recorded based on the agreement of participants. After the interview, the interview data were transcribed into verbal scripts.

\section{Reliability and validity of research}

The procedure of collecting, transcribing and analyzing data was loyal to the original recording files and we also used triangulation to examine interview context, recording of participants' problem-solving and so on. In order to reduce researchers' bias, we must assure that all the data were close to participants' thought. Therefore, this study had good reliability and validity.

\section{Result and Finding}

Each learning level student all agreed that digital animation can help them learn mathematics effectively. 
Followings are some students' responses about integrating digital animation into mathematics teaching, and S1, S2 and S3 are low, middle and high learning level students respectively.

\section{Low achievement student responded that it was clearer to catch the mathematics concepts if teacher used the digital animation materials}

Researcher inquired S1 the question "Comparing with previous studying method, what differences do you feel?" followings were S1's original responses.

Q: OK, that's all right, well...Comparing with teacher's previous studying method, what differences do you feel? In order words, is there any difference between previous teaching method and now digital animation teaching method?

\section{S1: Digital method is clearer.}

As for participant's answer "It is clearer", we wanted to know more about the answer so keeping asked for the details:

Q: It is clearer! For example, what part do you think it is clearer? S1: $m m \ldots$

Q: What part? The half...

S1: Fraction

The key concept of the digital animation was to compare the fractional size. "Half" in the context was the process when comparing fractional size. Students applied $1 / 2$ as a benchmark to decide which one is bigger or smaller.

Middle achievement student believed that animation materials could make classroom more vivid and interesting and let mathematical concepts easier to understand

Researcher asked S2 to answer the question: "Comparing with previous studying method, what differences do you feel?" followings were S2's original responses.

\section{S2: Yes, animation is more interesting.}

Except for interesting, in order to know more about the S2's feeling, researcher asked S2 the question "Do you like mathematics more if teacher uses digital animation materials, and why?"

S2: Mm...I feel that it is not that difficult. It is much more simplify.

Q: Mm...you mean animation makes difficult concept easier to understand.

S2: Yes.

Q: It makes you easy to learn.

S2: Yes.

From the above original context, S2 believed that integrating animation into mathematics classroom not only made mathematics interesting, but also let mathematical concepts be easy to understand. As for the understanding, we can analyze the following original context.

Q: Which part of fraction concepts will help you understand?

(The question refers to comparing number of fraction)

S2: Mm...I will find a common denominator.

Q: Oh, you use the common denominator so what do you feel the half method to compare number that teacher uses?

S2: It is faster.

From the original context, S2 believed that integrating digital animation into mathematics classroom helped him understand the concepts of comparing fractional size. Before presenting digital animation, participant used to utilize the traditional strategy, but now S2 could apply the idea of benchmark and agreed that it was the faster way to solve the problem.

High achievement student thought that animation materials can make interaction in classroom more vivid and interesting

S: More interaction, it is fun if we have interaction.

Q: Oh, so you like the kind of interaction.

S3: Yes.

From the above discussions, we could find that high achiever S3 liked digital animation because it provided certain functions that students could operate by themselves and teacher and students could discuss together in classroom. To recognize S3's thinking about digital animation, researcher asked S3 about her feelings related to digital animation teaching (Figure 1).

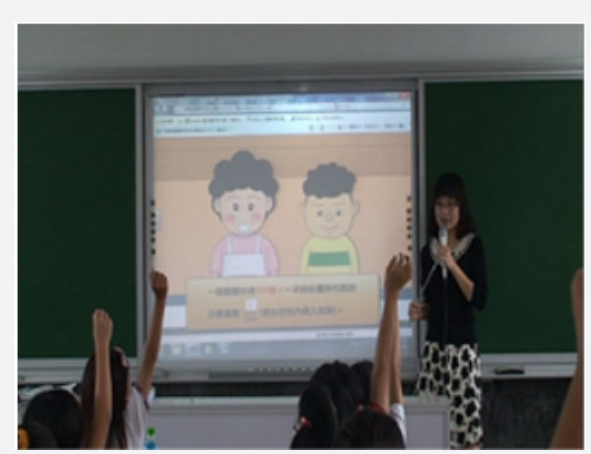

Figure 1: The situation of teaching with digital animation materials.

Q: Okay, how do you feel that teacher use the digital animation materials?

S3: $M m \ldots$

Q: Do you feel...

S3: It is kind of interesting.

Q: Anything else except for interesting? 


\section{S3: Mm...it seems easier to understand the math concept.}

To sum up, three different level students all agreed that with digital animation, teacher can express the mathematical concepts clearer, and made tedious mathematics class become more vivid and interesting. Most important of all, they all agreed that digital animation materials could help them learn mathematics effectively.

\section{The changing of liking mathematics from "okay" to "yes"}

We want to know whether students liked mathematics more by integrating digital animation into mathematics class or not from this research. Followings were original responses before presenting digital animation. Their answers were "okay" coincidently.

I:

\section{Q: Do you use to like mathematics class?}

S1: So so!

II:

Q: Well, do you use to like mathematics class?

S2: Okay...

III:

\section{Q: All right, do you use to like mathematics class?}

S3: Mm...Okay.

From the original responses, boring and difficult would be the reasons that made mathematics class to be not popular among students no matter what levels of students. However, after presenting digital animation, students started to like mathematics. Details as following;

\section{I:} math?

Q: Do you like math after teacher uses digital animation to teach

\section{S1: Yes.}

II:

Q: Ok, use...comparing previous math class, do you a little more like math when teacher use digital animation to teach math?

S2: Yes.

III:

Q: It is easier to understand. Well, do you a little more like math when teacher use digital animation to teach math?

\section{S3: Mm...Yes.}

We could find that no matter what levels of students would like mathematics class more after integrating digital animation into mathematics class, and obviously they did not reject the new technology teaching materials.

\section{Conclusion}

Because tedious and abstruse are the common sense for mathematics learning, most students did not like mathematics. Mathematics is always the last choice for most students. In addition, the mathematical concepts of grade 5 and 6 are more complicated so that many students usually give up learning mathematics. However, using digital animation to assist teaching and building a realistic situation and interaction between teacher and students are the method to make mathematical concepts to be easier to study. Students are not afraid of mathematics class because of the vivid and interesting learning environment.

Integrating digital animation into mathematics teaching can trigger students' learning interest. With learning interest, students will study mathematics voluntarily. Compare with other subjects, mathematics is more difficult to learn, so the fundamental method is to let students have interest in learning mathematics. In this study, no matter what level of students all accepted digital animation and the attitude to mathematics from "okay" becomes "yes". We noticed that students' learning interest has high influence on studying mathematics; therefore, how to raise students' learning interest is one of the key issues we must work on it. From the aspect of triggering students' learning interest, the benefit on digital animation teaching materials is quite workable and considerable.

\section{Acknowledgement}

This paper is a part of a research project supported by the National Science Council, Taiwan with grant no. NSC 105-2511-S-415-003-MY3. Any opinions expressed here are those of the authors and do not necessarily reflect the views of the Ministry of Science and Technology, Taiwan.

\section{References}

1. Bennison, A, Goos, M (2010) Learning to teach mathematics with technology: A survey of professional development needs, experiences and impacts. Mathematics Education Research Journal 22(1): 31-56.

2. National Council of Teachers of Mathematics (2000) Principles and Standards for School Mathematics. Reston, VA: NCTM. US.

3. Forster, p (2006) Assessing technology-based approaches for teaching and learning mathematics. International Journal of Mathematical Education in Science and Technology 37(2): 145-164.

4. Taylor, Pountney, Malabar I (2007) Animation as an aid for the teaching of mathematical concepts. Journal of Further and Higher Education 31(3): 249-261.

5. Yang DC, Tsai YF (2010) Promoting sixth graders' number sense and learning attitudes via technology-based environment. Educational Technology and Society 13(4): 112-125.

6. Yang DC, Li MN (2013) Assessment of animated self-directed learning activities modules for children's number sense development. Journal of Educational Technology and Society 16(3): 44-58.

7. Olive J, Lobato J (2008) The learning of rational number concept of using technology. In: MK Heid, GW Blume (Eds.), Research on technology and the teaching and learning of mathematics: Research syntheses 1: 1-53. Charlotte, NC: Information Age. North Carolina. 
8. McIntosh, Reys BJ, Reys RE, Bana J, Farrel B (1997) Number sense in school mathematics: Student performance in four countries. Perth Edith Cowan University, Australia.

9. Reys RE, Yang DC (1998) Relationship between computational performance and number sense among sixth- and eighth-grade students in Taiwan. Journal for Research in Mathematics Education 29(2): 225-237

This work is licensed under Creative Commons Attribution 4.0 License

DOI: 10.19080/ASM. 2019.03.555613
10. Gegner JA, Mackay DHJ, Mayer RE (2009) Computer-supported aids to making sense of scientific articles: cognitive, motivational, and attitudinal effects. Education Technology Research Development 57(1): 79-97.

11. Mayer R (2003) The promise of multimedia learning: using the same instructional design methods across different media. Learning and Instruction 13(2): 125-139.

\begin{tabular}{|l|}
\hline \multicolumn{1}{|c|}{ Your next submission with Juniper Publishers } \\
will reach you the below assets \\
- Quality Editorial service \\
- Swift Peer Review \\
- Reprints availability \\
- E-prints Service \\
- Manuscript Podcast for convenient understanding \\
- Global attainment for your research \\
- Manuscript accessibility in different formats \\
( Pdf, E-pub, Full Text, Audio) \\
- Unceasing customer service \\
Track the below URL for one-step submission \\
https://juniperpublishers.com/online-submission.php \\
\hline
\end{tabular}

